\title{
Strategi Kebijakan Luar Negeri Indonesia dalam Meningkatkan Daya Tawar Di Kawasan Indo-Pasifik
}

\author{
Suwarti Sari ${ }^{1}$ \\ Mariane Olivia Delanova ${ }^{2}$ \\ ${ }^{1}$ Hubungan Internasional/Fakultas Ilmu Sosial dan Ilmu Politik/ \\ Universitas Jenderal Achmad Yani \\ suwarti.sari@lecture.unjani.ac.id \\ ${ }^{2}$ Hubungan Internasional/Fakultas Ilmu Sosial dan Ilmu Politik/ \\ Universitas Jenderal Achmad Yani \\ delanovamariane@gmail.com
}

\begin{abstract}
The development of the concept of the Indo-Pacific region with the background of competition from the United States and China, which is perceived as a threat to the stability and national interests of the countries in the region. Indonesia and India, both use and strengthen maritime capabilities as their geopolitical strength through defense cooperation as an aspect of supporting their bargaining position in the region. This research will discuss and evaluate the form of defense cooperation undertaken by Indonesia and India in strengthening maritime affairs through joint training and enhancing their military capabilities to demonstrate how relevant their commitment is to this cooperation and to the objectives of the Act-East India Policy and the Indonesian World Maritime Axis. in the Indo-Pacific region. Their cooperation not only aligns their foreign policy in the region, but also gives them the opportunity to at least show major powers such as the United States and China that they have strategic power in the region that is worthy of consideration in a dynamic global political structure. In answering the problem formulation as the aim of this study, the researcher uses qualitative research methods that describe and analyze the relationship between the interests of Indonesia and India and the implementation of defense cooperation. By collecting data through literature studies and interviews with relevant sources with the data needed to support this research.
\end{abstract}

Keywords: Indo-Pacific, Act-East, World Maritime Axis, Geopolitics, Defense Cooperation

\section{Pendahuluan}

Kawasan Indo-Pasifik menjadi sebuah konsep wilayah yang muncul karena dinamika kawasan Asia Pasifik yang pada dasarnya mengacu pada penyatuan Samudera Hindia dengan Samudera Pasifik (Chen, 2018). Dengan konsep kewilayahan yang luas dan mencakup berbagai negara di 
dalamnya, membuatnya menjadi sebuah kawasan yang memiliki kepentingan politik yang kompleks. Tidak hanya melibatkan negara-negara berkembang seperti halnya negara anggota ASEAN termasuk Indonesia, tetapi juga kawasan ini sudah menjadi perhatian oleh negara besar seperti Amerika Serikat dan Tiongkok. Amerika Serikat menjadi negara yang paling mendominasi di kawasan Asia Pasifik sebagai offshore balancer dengan segala kepentingannya mengenai penguatan aliansi dan pengaruh sejak setelah perang dunia kedua (Jash, 2019). Dengan perubahan dinamika politik seperti munculnya Tiongkok sebagai kekuatan baru di kawasan Asia Pasifik, seiring dengan berkembangnya konsep Indo-Pasifik ini tentu tidak akan lepas dari perhatian Amerika Serikat sebagai ancaman baru.

Amerika Serikat maupun Tiongkok melancarkan kepentingannya untuk kemudian menentukan dinamika politik di kawasan melalui kebijakan strategis mereka yang bertujuan untuk tidak hanya mempertahankan namun juga memperluas pengaruhnya ke negara-negara di kawasan Indo-Pasifik. Keduanya memperkuat ikatan kerjasama dengan negara-negara tertentu, seperti halnya Amerika Serikat melalui The Quad. Amerika Serikat memperkuat kerjasama The Quad bersama India, Jepang dan Australia secara spesifik bertujuan menekan peningkatan kekuatan Tiongkok (Tsvetov, 2017). Artinya bahwa Amerika Serikat menaruh atensi pada Tiongkok sebagai ancaman yang mengganggu pengaruhnya di kawasan Indo-Pasifik. Dengan Tiongkok melalui BRI atau Belt and Road Initiative yang lebih menggunakan pendekatan dengan negara-negara berkembang lewat kerjasama pengembangan konektivitas dan ekonomi di kawasan Indo-Pasifik. Kebijakan BRI menurut Xi Jinping akan terus diperluas sebab sejauh ini sudah mencapai keberhasilan atas terbukanya konektivitas dengan peningkatan infrastruktur dengan mitra kerjasama yang beragam (Minghao, 2020). Dengan kebijakan tersebut yang sudah memberikan banyak keuntungan bagi Tiongkok, Tiongkok juga terus memperkuat serta memperluas hubungannya dengan negara-negara mitra untuk kemanfaatan dan pertahanan pengaruhnya di kawasan.

Mengacu pada persaingan Amerika Serikat dan Tiongkok dan atensi mereka terhadap kawasan Indo-Pasifik inilah yang menjadi sebuah faktor 
atas kemungkinan munculnya intervensi baik secara langsung atau tidak langsung dari Amerika Serikat dan Tiongkok yang mengganggu dan mempengaruhi kepentingan negara-negara lain yang termasuk ke dalam konsep kewilayahan Indo-Pasifik. Diperlukannya sikap bagi negara-negara lain di kawasan, khususnya negara berkembang yang menjadi objek perluasan pengaruh Amerika Serikat dan Tiongkok, untuk juga dapat meningkatkan dan mempertahankan pengaruh serta kekuatannya sendiri di kawasan melalui kerjasama strategis sebagai upaya terbaik bagi negara yang masih memiliki kapabilitas rendah dalam segi pengaruhnya di kawasan. Seperti halnya Indonesia dan India yang juga memiliki kepentingan di kawasan Indo-Pasifik.

Bagi Indonesia, kawasan Indo-Pasifik menjadi sebuah konsep wilayah yang melibatkan ASEAN sebagai kawasan yang paling strategis. Menurut Menteri Luar Negeri Indonesia, Retno Marsudi menyampaikan bahwa sentralitas ASEAN memegang peran penting di kawasan Indo-Pasifik untuk dapat memoderasi kepentingan serta mengakomodasi peran negara anggotanya untuk maju di kawasan (Kementerian Luar Negeri, 2018). Dengan kepentingan Indonesia yang juga menekankan sentralitas ASEAN sebagai media dalam perwujudan tujuan kebijakan luar negerinya, termasuk Poros Maritim Dunia. Menurut Presiden Republik Indonesia, Joko Widodo dalam pertemuan East Asia Summit ke-13 menyatakan pentingnya kerjasama maritim untuk memastikan stabilitas keamanan Samudera Pasifik dan Samudera Hindia sebagai Single Geo-Strategic Theatre (KSP, 2019). Hal tersebut menjelaskan bahwa Kebijakan Poros Maritim Dunia bagi Indonesia menjadi penting dengan fokus di kawasan Indo-Pasifik dengan kerjasama maritim yang bisa terus diperkuat dengan negara-negara lain di kawasan, baik melalui ASEAN sebagai organisasi kawasan yang strategis maupun kerjasama dengan negara di luar keanggotaan ASEAN, termasuk India.

India sendiri menjadi salah satu negara yang fokus dan mendukung konsep "Indo-Pacific Strategy" sebagai bagian strategi perwujudan kepentingannya di kawasan Asia Pasifik (Chen, 2018). India memiliki atensi sebagai negara berkembang untuk dapat memiliki pengaruh dan daya tawar 
di kawasan yang kuat dengan menjalin banyak kerjasama dengan beragam negara baik negara maju maupun berkembang, kebijakan itu adalah kebijakan Act East. Kebijakan Act East sebagai bentuk baru dari kebijakan Look East Policy milik India meningkatkan kerjasama dengan negara-negara di Asia Tenggara maupun Asia Timur (Vietnam News Agency, 2013).

Dengan memperluas hubungan kerjasama yang strategis baik dengan negara-negara yang memiliki peran maupun letak strategis di kawasan Indo-Pasifik membuka peluang bagi India untuk dapat meningkatkan keuntungan atas kepentingan maupun perannya sehingga India menjadi sebuah negara yang patut dipertimbangkan di tengah-tengah perkembangan aspek ekonomi, pertahanan maupun intensitas hubungan internasionalnya.

Kunjungan resmi Perdana Menteri India ke Indonesia, Narendra Modi sepakat dengan Presiden Joko Widodo untuk memiliki kepentingan yang sama atas persepsi kerjasama maritim yang harus ditingkatkan di Indo-Pasifik (Ministry of External Affairs Government of India, 2018). Penelitian ini akan menjelaskan bagaimana strategi Indonesia dalam meningkatkan posisi tawarnya di kawasan Indo-Pasifik, salah satunya melalui kerjasama dengan India yang dilatarbelakangi oleh aspek geopolitik. Hal tersebut dijadikan sebagai orientasi kebijakan strategis dalam meningkatkan peran dan pengaruh Indonesia dan India di kawasan melalui penguatan kerjasama maritim dengan fokus aspek stabilitas pertahanan dan keamanan maritim kawasan.

Artikel ini ingin menganalisa mengenai strategi Indonesia dalam meningkatkan posisi tawar di kawasan Indo-Pasifik, terutama melihat perkembangan berbagai perkembangan dinamika di kawasan tersebut.

\section{Pembahasan}

Bagi Indonesia, meskipun dengan Poros Maritim Dunia-nya, untuk dapat mengelola kawasan Indo Pasifik tetap masih dibutuhkannya sentralitas ASEAN yang dapat menghimpun dan menjadi media untuk memoderasi kepentingan negara-negara yang ada di kawasan (Putri Auliya 
dan Yohanes Sulaiman, Jurnal Global \& Strategis, 2019). Sebab, terlepas dari motivasi Indonesia yang ingin secara independen berkontribusi di kawasan tidak akan cukup untuk melancarkan kepentingannya, itulah mengapa dengan adanya media komunikasi kerjasama itu penting. Media yang dapat menyeragamkan persepsi dan meminimalisir segala bentuk miskomunikasi, menjadikan ASEAN tidak hanya sebagai organisasi kawasan yang strategis bagi Indo Pasifik, namun juga menjadi sebuah media bagi Indonesia untuk bisa melancarkan kepentingannya di kawasan terkait.

Mengacu dari, Rencana Strategis Kementerian Luar Negeri Indonesia 2015-2019, Indonesia sendiri memiliki kebijakan untuk dapat meningkatkan tidak hanya Peran namun juga Kepemimpinan Indonesia dalam Kerja Sama ASEAN (Kementerian Luar Negeri Republik Indonesia, 2015). Hal ini menunjukkan bahwa kepentingan Indonesia terkait peningkatan citranya yang dimulai dari kawasan terdekat, yakni Asia Tenggara berusaha untuk dilancarkan melalui ASEAN masih tetap relevan. Sebagai negara yang memiliki fokus pada kontribusi dan inisiatif dalam mekanisme kerjasama ASEAN, khususnya melalui ASEAN led-mechanisms, dalam praktisnya Indonesia terus memberdayakan kekuatan ASEAN sebagai aktor yang memiliki peran penting dalam segala isu yang berkembang dan memiliki kaitan dengan stabilitas politik maupun keamanan di sekitar kawasannya.

Hal ini berlaku bagi Indonesia dalam memandang kawasan Indo Pasifik sebagai kawasan yang menekankan kepentingannya dalam mempertahankan posisi daya tawarnya. Menjadikan Indo Pasifik sebagai kawasan yang strategis bagi posisi daya tawarnya tidak terlepas dari bagaimana perkembangan secara politik dan ekonomi di kawasan ini menjadi pesat dari waktu ke waktu. Menjadikan kawasan ini sebagai lingkungan strategis bagi kebijakan luar negeri Indonesia dengan didasari kepentingannya akan menjadi dasar bagi Indonesia untuk juga melihat bagaimana negara lain memandang dan memiliki pendirian atas kawasan Indo Pasifik. Tindakan terkait dibutuhkan untuk bisa mempertimbangkan strategi apa yang dibutuhkan oleh Indonesia dalam menjalin hubungan dan 
kerjasama khusus dengan negara tertentu yang memiliki kepentingan sejalan dengan strategi Indonesia.

Pandangan India terhadap Indo Pasifik menjadi semakin penting mengingat bahwa Indo Pasifik menjadi hal sentral dalam kebijakan luar negeri India sebagai negara yang termasuk ke dalam kawasan terkait. Kini India memiliki strategi untuk mewujudkan Free and Open Indo-Pacific dengan memperkuat kerjasama dan integrasi IORA atau Indian Ocean Rim Association, ASEAN dan The Quad (Thakker, 2019).

Hal ini kemudian dilakukan untuk menunjukkan perhatian India terhadap kawasan terkait, namun juga memperlihatkan bahwa India menggunakan konsep Indo Pasifik ini sebagai ruang untuk mewujudkan kepentingannya. Karena keberadaan konsep Indo Pasifik juga tidak terlepas dari Samudera Hindia sebagai kawasan dengan pengembangan ekonomi yang terus meningkat dibandingkan dengan Samudera Pasifik yang sudah lebih maju, India dengan letaknya yang bersentuhan langsung memiliki peran penting (Bhatt, 2018). Posisi India di Samudera Hindia inilah yang menjadi justifikasi mengapa kontribusi India dalam pergerakan politik di kawasan Indo Pasifik menjadi relevan.

Menurut Direktur Kerja Sama Eksternal ASEAN/Acting Ketua SOM ASEAN-Indonesia, Benny Y.P. Siahaan, menyatakan bahwa ASEAN dan India kemudian dapat saling mengembangkan atensi dan kepentingan yang sama pada pada kerja sama dalam bidang maritim secara proaktif dan konkret di kawasan Indo Pasifik (Kementerian Luar Negeri Republik Indonesia, 2019). Pernyataan ini kemudian disampaikan pada Pertemuan Ke-21 ASEAN-India Senior Officials' Meeting (AISOM) di New Delhi, India pada tanggal 11-12 April 2019. Hal ini tidak terlepas dari beberapa aspek penting yang berusaha dijamin oleh kedua pihak seperti halnya dalam masalah keamanan dan keselamatan maritim, penanganan sampah plastik laut, konektivitas maritim, dan aspek penting lainnya.

Adanya koordinasi yang dijalankan oleh kedua Menteri Luar Negeri Indonesia dan India tidak hanya fokus pada pembahasan beragam upaya untuk meningkatkan hubungan bilateral kedua khususnya di bidang ekonomi dan maritim. Namun juga karena Indonesia dan India dua negara 
maritim, pokok bahasan kerja sama maritim antara kedua negara menjadi penting untuk didiskusikan. Seperti halnya Pertemuan Joint Task Force antara Republik Indonesia dan India sebagai pengembangan lanjutan konektivitas dan kerja sama antara Aceh dan Andaman-Nicobar serta berkomitmen untuk mempercepat penyelesaian batas maritim di Zona Ekonomi Eksklusif kedua negara (Kementerian Luar Negeri Republik Indonesia, 2019). Semua menjadi semakin kuat dan relevan saat keduanya, baik Indonesia maupun India secara proaktif memberikan beragam dukungan terhadap ASEAN Outlook on Indo-Pacific sebagai wujud atensi mereka dalam mengembangkan partisipasi dalam dinamika kawasan Indo Pasifik.

Serangkaian kerjasama pertahanan yang dibangun oleh India dengan pilihan mitra kerjasama dari beberapa negara ASEAN tidak terlepas dari perkembangan politik kawasan. Begitupun dengan upaya dalam penguatan kerjasama maritim kedua negara, pakar hubungan Indonesia-India dari Paramadina Graduate School of Diplomacy, Ahmad Qisa'i menilai kesepakatan tersebut memberikan keuntungan yang lebih besar bagi India, terkait ketahanan pasokan energi nuklir India dimana pasokan bahan baku nuklir dari Australia dan minyak dari Vietnam berkesinambungan, dimana akses pengirimannya melewati wilayah Indonesia dan ASEAN (Lutfia, 2018). Dengan begitu semakin mendorong urgensi kerjasama maritim India dengan Indonesia menjadi langkah penting bagi jaminan keberlangsungan arus lalu lintas bahan baku sumber daya energi India. Sehingga jika India menekankan pentingnya kerjasama ini untuk kepentingan sehingga harus terus berlanjut, Indonesia juga memiliki urgensi atas posisi daya tawarnya di kawasan yang memiliki nilai potensi cukup besar.

Tidak hanya pembahasan mengenai arsitektur kawasan Indo Pasifik yang di dalamnya melibatkan persaingan antar hubungan negara-negara besar. Namun juga tindakan yang dilakukan baik Indonesia maupun India menunjukkan kesamaan bagi mereka dalam memandang bagaimana kedua negara memiliki preferensi untuk ikut serta dalam dinamika politik kawasan. Keikutsertaan mereka dalam dinamika politik kawasan ini menunjukkan bahwa mereka mengambil adanya kesempatan dan peluang 
dalam mempertahankan posisi serta daya tawar mereka dengan adanya kelebihan atas posisi maupun kepentingan strategis di kawasannya. ASEAN yang saat ini tengah mengembangkan ASEAN Indo-Pacific Outlook bahkan menyambut baik komitmen India untuk berkontribusi pada pengembangan arsitektur kawasan Indo Pasifik.

Mekanisme East Asia Summit yang telah dimiliki ASEAN saat ini akan memudahkan implementasi dan pemajuan kerja sama dimaksud. Dengan adanya pernyataan yang melibatkan ASEAN, melihat bahwa ada korelasi yang signifikan tentang bagaimana Indonesia secara aktif terhadap India untuk bisa memproyeksikan kepentingan dan kerjasama di bidang maritim dengan India secara langsung maupun melalui ASEAN agar motif mereka dapat dimoderasi secara jelas. Kerja sama ASEAN dan India telah dimulai pada tahun 1992 dan secara resmi India menjadi Mitra Wicara ASEAN pada 1995. Kerja sama ASEAN-India mencapai tingkat Kemitraan Strategis pada 2012. Pada tahun 2018, ASEAN dan India merayakan hubungan kerja sama 25 tahun kemitraan dengan penyelenggaraan KTT Peringatan ASEAN-India di New Delhi tanggal 25 Januari 2018.

Dalam hal tersebut, Vijay Thakur Singh, ketua Delegasi India mengapresiasi Indonesia atas inisiatif pelaksanaan Pertemuan High Level Dialogue on Indo-Pacific Cooperation tanggal 20 Maret 2019 di Jakarta yang dinilai bermanfaat dan tepat waktu. Ia menegaskan pula komitmen India untuk menjaga stabilitas, perdamaian, dan kemakmuran di kawasan (Kementerian Luar Negeri Republik Indonesia, 2019).

Terlepas dari bagaimana ASEAN memoderasi pandangan dan keinginan keduanya untuk terlibat aktif di kawasan, hal ini memperkuat bagaimana Indonesia dan India senantiasa mempertimbangkan kerjasama yang bisa dijalin keduanya sehingga kerjasama yang dijalankan bisa saling menguntungkan. Keuntungan dan manfaat yang bisa diambil oleh Indonesia dan India ini perlu diutamakan di tengah situasi geopolitik yang dinamis dan upaya negara besar memperebutkan pengaruh di kawasan Indo-Pasifik. Sehingga di tengah persaingan yang ada, keduanya masih tetap bisa proaktif dalam dinamika politik namun tetap fokus pada tujuan 
dan kepentingan masing masing melalui kerangka kerjasama, khususnya dalam bidang maritim.

Menteri Luar Negeri India, Dr. Subrahmanyam Jaishankar melakukan pertemuan dengan Menlu Retno Marsudi di Jakarta, Kamis pada 5 September 2019, sebagai bagian dari kunjungan dua harinya ke Indonesia, dengan beberapa fokus dalam diskusi bersama Menteri Luar Negeri Republik Indonesia Retno Marsudi menyangkut beberapa hal penting seperti halnya dinamika hubungan keduanya termasuk sejumlah masalah regional, masalah global, masalah politik, masalah keamanan, masalah ekonomi (Redaksi WE, 2019).

Indonesia dan India memiliki hubungan yang erat karena memiliki banyak persamaan, terutama sebagai dua negara multi etnis terbesar di dunia, dan kedekatan hubungan sejarahnya, dimana di tahun 2019 India dan Indonesia merayakan peringatan 70 tahun hubungan diplomatik yang terjalin di antara kedua negara. Tidak hanya karena mempererat hubungan diplomatik antara Indonesia dan India yang sudah terjalin lama, adanya kunjungan ini menurut Jaishankar adalah bagian dari rangkaian kunjungan yang dilakukan Perdana Menteri India Narendra Modi.

Kunjungan lanjutan ini menunjukkan adanya persamaan dalam strategi India untuk menjaga hubungan kerjasama dengan Indonesia, sehingga merefleksikan bahwa dari sisi India, India melihat Indonesia sebagai rekan kerjasama yang patut dipertimbangkan dan dipertahankan. Bahkan untuk banyak kepentingan, hubungan kerjasama di antara keduanya harus ditingkatkan dan dikembangkan. Hal ini disebabkan keduanya melihat satu sama lain memiliki potensi dan posisi strategis di kawasan yang akan menjadi besar ketika bisa diselaraskan. Konteks diskusi yang lebih besar di antara Indonesia dan India bahkan sejak kunjungan Perdana Menteri Narendra Modi pada Mei 2018, memegang peran penting bagi perkembangan hubungan bilateral Indonesia-India dimana keduanya sepakat bahwa hubungan mereka perlu ditingkatkan menjadi hubungan kemitraan strategis yang komprehensif. Kesepakatan antara Indonesia dan India dalam memperkuat aspek kerjasama dalam bidang pertahanan dan maritim yang dikhususkan dalam kawasan Indo 
Pasifik ini menjadi salah satu poin penting dalam 15 kesepakatan yang ditetapkan oleh pemerintah Indonesia melalui Presiden Jokowi dan pemerintah India melalui Perdana Menteri Narendra Modi yang ditetapkan pada Rabu, 30 Mei 2018 (Lutfia, 2018).

Kunjungan yang telah dilakukan membahas pula beberapa agenda seperti ASEAN Outlook terkait Indo-Pasifik yang dipromosikan Indonesia, Kemitraan Ekonomi Komprehensif Regional (Regional Comprehensive Economic Partnership/RCEP), pembukaan akses pasar kelapa sawit, dan kerja sama pertahanan. Dalam kunjungan ini India menekankan bahwa adanya tujuan bersama antara India dengan Indonesia tentang koperasi maritim di Indo Pasifik yang disepakati selama kunjungan Perdana Menteri Narendra Modi tahun lalu, adalah pengakuan bahwa India dan Indonesia sebagai dua ekonomi utama di kawasan ini, perlu mengembangkan sinergi untuk jujur pada potensi dan membuat tantangan yang dihadapi kawasan Indo Pasifik (Redaksi WE, 2019). Dengan adanya penekanan ini, urgensi kedua nya dalam memandang kawasan Indo Pasifik dengan atensi kepentingan mereka menjadi lebih kuat dimana Menteri Luar Negeri India menyampaikan dukungan kuat negaranya ada visi Indo Pasifik yang dipromosikan Indonesia.

Adanya motif yang sejalan untuk membangun kerjasama pada konsep Indo Pasifik dalam Asia Tenggara, tidak melepaskan dari pandangan keduanya untuk juga melihat ASEAN yang bisa memoderasi dan memperkuat implementasi kerjasama serta potensi keuntungan dalam memperkuat posisi daya tawarnya di kawasan. Tidak hanya sikap proaktif Indonesia terhadap kawasan Indo Pasifik juga sama sama memberikan pengaruh, seperti halnya dinamika yang terjadi di Indo Pasifik mempengaruhi India baik secara langsung maupun tidak langsung, maka dari itu dibutuhkan kebijakan bagi India untuk tetap unggul dan aktif dalam memperjuangkan stabilitas kawasan untuk kepentingannya. Motivasi yang melatarbelakangi India untuk terus aktif di kawasan Indo Pasifik memiliki relevansi dengan kebijakan Act East-nya dengan fokus mengintegrasikan ekonomi maupun keamanan daerah Asia Tenggara sekaligus Asia Timur (Sighn, 2020). Atensi India dalam menjalankan 
kepentingannya melalui Act-East sekaligus menjadikan kawasan Indo Pasifik sebagai lingkungan strategis mengingat letak India yang menjadi kunci di kawasan menjadi justifikasi mengapa India meningkatkan posisi daya tawar di kawasan ini dengan hubungan kerjasama multidimensi dan terintegrasi.

Kebijakan Act-East yang dilaksanakan oleh pemerintah India bertujuan untuk mengembangkan hubungan khususnya dengan negara ASEAN dengan berlandaskan unsur Budaya, Konektivitas dan Komersil (Sighn, 2020). Maka dari itu, tidak hanya Indonesia yang memandang keberadaan ASEAN menjadi penting dalam memoderasi kepentingan di kawasan Indo Pasifik, India melalui kebijakannya merefleksikan pentingnya posisi ASEAN di kawasan yang jika hubungan kerjasama antara India dan negara ASEAN bisa berjalan dengan kuat dan terjaga, hal ini sekali lagi akan menunjang kepentingan dan daya tawar India di kawasan. Pilihan India maupun Indonesia dalam menghimpun kepentingan dalam kerjasama menurut liberalisme adalah sebuah usaha pembentukan jaringan interdependensi yang dapat menekan potensi konflik (John Baylis, Steve Smith dan Patricia Owens, 2008). Artinya bahwa semakin sebuah negara memiliki intensi untuk dapat mengkomunikasikan kepentingannya melalui kerjasama dalam bidang tertentu, maka semakin terbentuknya hubungan keterkaitan yang saling menguntungkan akan mendorong negara-negara yang terlibat untuk terus memperkuat dan bahkan memperluas bidang kajian kerjasama yang ada.

Relevansi Poros Maritim Dunia dan Act East dalam Konsep Indo Pasifik menjadi semakin kompleks, tidak hanya didasari atas kepentingan perwujudan kebijakan luar negeri yang dimiliki oleh Indonesia maupun India, dan dukungan mereka atas ASEAN sebagai media komunikasi di kawasan Indo Pasifik, namun juga didukung dengan adanya keinginan atas implementasi kekuatan geopolitik sebagai kelebihan mereka yang dapat digunakan secara strategis di tengah-tengah kawasan Indo Pasifik yang menjadikan posisi mereka semakin penting dalam pergerakan politik yang ada di kawasan. Hal yang menjadi kesamaan bagi keduanya adalah visi khususnya dalam kerjasama maritim di wilayah Indo Pasifik sebab hal ini 
tidak terlepas dari India yang juga memiliki posisi sentral di Indo Pasifik dengan garis pantai sepanjang 7.500 kilometer, dari 1.380 pulau dan lebih dua juta kilometer persegi Zona Ekonomi Eksklusif dengan Indonesia merupakan negara kepulauan terbesar di dunia dengan total wilayah maritim sebesar 6.400.000 kilometer persegi (Lutfia, 2018).

Indonesia dan India sama-sama mendorong bagaimana kawasan Indo Pasifik yang mencakupi Samudra Hindia dan Samudra Pasifik terjamin keamanannya dan stabil secara politis maupun praktis. Artinya sebagai jalur yang digunakan sebagai akses dengan konektivitas yang besar, kawasan ini harus tetap terjamin secara damai dan aman untuk perdagangan dunia, tidak digunakan sebagai platform untuk perebutan sumber daya alam, perselisihan teritorial atau supremasi maritim sebagaimana pernyataan yang dikeluarkan Presiden Jokowi menyampaikan visi pemerintahannya dalam KTT Asia Timur pada 2014. Disisi yang lainnya India dengan mengembangkan kebijakan “Look East” India yang diterapkan pada 1992 menjadi “Act East". Geopolitik adalah bagaimana sebuah negara menggunakan faktor geografi dalam sebuah praktis politik berupa kebijakan baik domestik maupun internasional tertentu (G. Evans \& J. Newnham, 1998). Mengacu dari posisi dan peran strategis yang dimiliki oleh Indonesia maupun India secara geografis, dimana keduanya bersentuhan dengan Samudera Hindia dan atau Samudera Pasifik, mempengaruhi kebijakan luar negeri yang diambil berupa Act-East milik India maupun Poros Maritim Dunia milik Indonesia.

Dorongan Presiden Jokowi mengajak India untuk mempercepat implementasi ASEAN Outlook on the Indo-Pacific (AOIP) tidak terlepas dari pandangan bahwa ASEAN dan India memiliki kesamaan pandangan dan aset yang dapat digunakan untuk saling mendukung kerja sama di kawasan sesuai dengan pernyataan Presiden Jokowi dalam menghadiri KTT ke-16 Asean-India yang berlangsung di Impact Exhibition and Convention Center pada 3 November 2019 (Amanda, 2019).

Apresiasi Indonesia dengan optimistik dan sikap proaktif India terhadap AOIP yang telah disahkan ASEAN pada Juni 2019 menjadi tindakan penguat atas pentingnya kerjasama maritim Indonesia dan India 
yang tidak terlepas dari usaha dalam menjamin stabilitas kawasan Indo Pasifik. Selain itu, dukungan India menunjukkan bahwa Indonesia menyusun strategi dengan meningkatkan hubungan kerjasama bersama India adalah langkah strategis yang mendorong posisi daya tawarnya semakin kuat di kawasan. Sebab dengan melibatkan India dan mendorongnya dalam mendukung kebijakan yang dikerjakan, akan lebih mempermudah jalan Indonesia untuk semakin meningkatkan posisi daya tawarnya. Maka dari itu, melalui semua ini juga merefleksikan bahwa India juga memiliki posisi daya tawar yang penting di kawasan sebab sudah menjadi negara mitra kerjasama strategis yang penting bagi Indonesia dan ASEAN, bahkan dengan kesediaannya dalam menyambut dan mendukung penuh AOIP.

Potensi yang menjadi pertimbangan bagi Indonesia untuk memilih India sebagai mitra strategis, khususnya pilihan dalam menjalin kerjasama maritim dan bertujuan untuk bisa membantu meningkatkan posisi daya tawar Indonesia salah satunya adalah pertumbuhan ekonomi India, jumlah penduduk yang besar, serta letak geografis yang serupa dengan Indonesia serta ASEAN (Amanda, 2019). Pertumbuhan ekonomi yang dimiliki oleh India tumbuh sebesar 7\%, jika kemudian melihat bagaimana pertumbuhan rata-rata ekonomi yang dimiliki oleh negara-negara di ASEAN yakni sebesar $5,1 \%$, jumlah pertumbuhan ini bisa kemudian saling dipertimbangkan sebagai acuan untuk bisa saling meningkatkan.

Selain itu jumlah penduduk yang besar dengan jumlah sebesar dua milyar populasi jika kemudian digabungkan antara India dengan ASEAN menjadi aset yang besar dan bisa dikembangkan dalam segi sumber daya manusia. Begitupun dengan posisi tiap negara yang menempati kawasan geografis yang sama, yakni berada di sekitar perairan Samudra Hindia yang memungkinkan ASEAN dan India untuk saling terhubung sekaligus memungkinkan India terhubungkan dengan kawasan Samudra Pasifik, dimana jika dikaitkan dengan kawasan Indo Pasifik maka negara-negara ini memiliki posisi yang strategis sebab menjadi kunci konektivitas dan pengembangan kawasan terkait. Hal ini yang menjadi menarik, sebab dengan adanya kepemimpinan Indonesia di ASEAN yang menjalin 
hubungan erat dengan India dengan kepemimpinannya yang patut dipertimbangkan, menjadi strategi kolaborasi yang potensial dan menguntungkan bagi keduanya untuk memegang kendali di kawasan Indo Pasifik terlepas dari rivalitas yang ada.

Bagi Indonesia sendiri, India merupakan mitra penting dimana baru-baru ini menyepakati kerja sama konektivitas yang saling menghubungkan wilayah terdekatnya, yakni Aceh dan Andaman-Nicobar. Kerja sama konektivitas tersebut antara lain dilakukan dalam bentuk peningkatan hubungan dagang melalui pelayaran ekspedisi pionir kapal dagang dari Banda Aceh ke Port Blair dan investasi di bidang infrastruktur yang mendukung konektivitas. Oleh karenanya, dalam Forum Infrastruktur dan Konektivitas Indo Pasifik yang akan diselenggarakan Indonesia pada 2020, Indonesia mengharapkan kehadiran dan peran serta India sebagai perwujudan dukungan bagi penguatan kerja sama Indo Pasifik (Amanda, 2019).

Dengan kebijakan yang berlandaskan kekuatan geopolitik, berupa bidang maritim yang menjadi keunggulan baik Indonesia maupun India, pada saat yang bersamaan menggunakan konsep Indo Pasifik sebagai konsep yang strategis bagi perwujudan kepentingan mereka. Selain itu, jalan ini ditempuh keduanya sebab mereka adalah sebuah negara berkembang dengan potensi pengembangan ekonomi yang cukup di kawasan. Jika mengacu kepada dokumen Visi Bersama Kerjasama Maritim India-Indonesia di Asia Pasifik yang dikeluarkan Kementerian Luar Negeri India, kedua negara memiliki posisi penting sebagai poros utama, sebab tidak hanya berada di kawasan Indo Pasifik, namun juga menjadi kunci yang menghubungkan Lautan Hindia dan Lautan Pasifik. Sehingga sebagai negara yang mempunyai perbatasan maritim, Indonesia dan India juga sepakat meningkatkan konektivitas antar kedua negara dengan membangun jalur maritim antara Pulau Andaman dan Nikobar dengan Sabang di Aceh yang diharapkan akan membuka potensi ekonomi antar kedua wilayah (Lutfia, 2018).

Kedua negara juga sepakat untuk mempercepat penyelesaian perundingan Perjanjian Kerjasama Transportasi Maritim ASEAN-India. Pada 
Januari lalu, India mengundang ke-10 pimpinan negara anggota ASEAN. Dengan berkontribusi dalam dinamika politik di wilayah Indo Pasifik, dan menggunakan keunggulan serta kekuatan geopolitik yang dimiliki mereka, maka akan semakin besar peluang bagi mereka untuk meningkatkan kekuatan atau posisi daya tawar mereka di kawasan terkait. Dan dengan memperhatikan atensi keduanya terhadap ASEAN sebagai media komunikasi dan kepentingan negara-negara di kawasan Indo Pasifik, akan semakin membuka peluang kerjasama bilateral antara Indonesia dan India untuk memperkuat relasi dan kerjasama di bidang maritim sebagai aspek penting di kawasan. Maka dari itu, implementasi The India-Indonesia Bilateral Maritime Exercise untuk daya tawar di kawasan Indo Pasifik menjadi relevan untuk dikaji berdasarkan kepentingan keduanya.

Kerjasama pertahanan Indonesia-India disepakati oleh Presiden Joko Widodo dan G. Mohan Kumar selaku Sekretaris Pertahanan India untuk terus ditingkatkan khususnya dalam pelatihan militer bersama dan kerjasama untuk bidang maritim setelah kunjungan resmi keduanya dilaksanakan (Prashanth, 2017). Adanya kesepakatan resmi yang ada, menjadi langkah nyata bagi keduanya untuk merealisasikan kepentingan mereka selaku dua negara yang memiliki kapabilitas maritim dan posisi strategis yang sama di kawasan Indo Pasifik. Implementasi penguatan hubungan pertahanan dilakukan dengan pelaksanaan sesi pertemuan dialog antar menteri pertahanan dan badan latihan militer bersama (Prashanth, 2017).Kerjasama pertahanan yang dilakukan dalam bidang maritim menjadi kekuatan terpenting bagi Indonesia dan India untuk bisa menciptakan stabilitas kawasan yang tentu dalam pelaksanaannya membutuhkan strategi dan rencana yang terus dikomunikasikan oleh pejabat kedua negara dengan spesialisasi di bidang pertahanan maupun maritim.

Pertemuan dan diskusi khusus juga dilakukan Menteri Pertahanan India Nirmala Sitharamanand dengan Menteri Pertahanan Republik Indonesia Ryamizard Ryacudu, serta berkoordinasi dengan Menteri Maritim Republik Indonesia Luhut Panjaitan dan Menteri Koordinator Bidang Politik, Hukum dan Keamanan Wiranto dengan sebagai pengembangan dari 
Comprehensive Strategic Partnership antara Indonesia-India untuk meningkatkan keamanan domain maritime (India Times, 2018). Dialog yang dilakukan antar pejabat yang sudah dilakukan menjadi dasar pelaksanaan kerjasama yang lebih terstruktur dan terencana, sebagai mitra kerjasama Indonesia yang strategis, India dan Indonesia melakukan aplikasi kerjasama dengan kegiatan patroli dan latihan bersama yang terkoordinasi yakni Samudera Shakti yang diadakan pada 13 November 2018 di Pelabuhan di Surabaya, Indonesia (GK Today, 2018).

Kerjasama yang dilakukan oleh Indonesia dan India di bidang maritim ini sekali lagi tidak terlepas dari keinginan mereka untuk menjaga stabilitas kawasan maritim untuk terus dapat terkendali di Samudera Hindia, yang menjadi kunci bagi kawasan Indo Pasifik. Fase yang dilakukan oleh TNI AL dan INS Rana of Eastern Fleet dalam latihan ini berupa fase pelabuhan dengan kegiatan berbagai kegiatan atraksi profesional, kunjungan geladak kapal, interaksi sosial dan peralatan olahraga, serta Fase Laut dengan kegiatan operasi joint manoeuvres, operasi helikopter, surface warfare exercise, anti-submarine warfare exercise dan anti-piracy exercises. Yang dilakukan oleh Indonesia dan India melalui kerjasama pertahanan dalam bidang maritim ini adalah bentuk yang relevan dengan diplomasi pertahanan. Sebab jika mengacu pada konsep diplomasi pertahanan menurut Winger bahwa Penggunaan kekuatan militer dalam cara damai melalui beberapa aktivitas negara-negara dalam ruang lingkup internasional, seperti hal-nya pertukaran perwira, kunjungan kapal-kapal, misi latihan hingga pelaksanaan latihan militer bersama sebagai bagian dari praktisnya (Gregory Winger, Vol 33:2014). Dengan adanya pelatihan-pelatihan yang dilakukan dan diperkuat oleh kedua negara, maka akan terbentuk hubungan bilateral yang didasarkan atas unsur kepercayaan dan upaya evaluasi melalui pertukaran informasi untuk membangun kekurangan yang ada di kedua belah pihak.

Menurut Presiden Joko Widodo, India adalah mitra strategis dengan harapan pengembangan kerjasama penunjang baik segi infrastruktur termasuk Pulau Sabang dan Kepulauan Andaman, serta pernyataan 
Perdana Menteri India Narendra Modi atas pentingnya ASEAN untuk kedamaian Indo Pasifik (India Writes, 2019).

Pada waktu yang akan datang, Indonesia dan India terus mengembangkan aspek kerjasama pertahanan khususnya dalam bidang maritim dan infrastruktur penunjang sejauh mereka masih memberikan atensi terhadap kawasan Indo Pasifik yang masih dijadikan sebagai lingkungan strategis bagi kebijakan luar negeri keduanya, Act-East dan Poros Maritim Dunia. Menteri Pertahanan Republik Indonesia H. Prabowo Subianto menerima kunjungan kehormatan Duta Besar India untuk Indonesia H.E. Mr. Pradeep Kumar Rawat pada Rabu 13 November 2019 di kantor Kementerian Pertahanan, Jakarta dimana kedua pihak membicarakan berbagai upaya untuk mempererat dan meningkatkan hubungan kerjasama bilateral antara Indonesia dan India di bidang pertahanan di bidang pelatihan dan pendidikan, yakni melalui pertukaran siswa dan pengajar (Kementerian Luar Negeri Republik Indonesia, 2019). Untuk di bidang pendidikan dan pelatihan, meskipun sudah berjalan sejauh ini namun perlu ditingkatkan kembali mengingat bahwa meningkatkan performa dan produktivitas prajurit menjadi kunci dari pasukan yang memiliki kualitas dengan standar yang tinggi dan sesuai dengan kebutuhan.

Kedua negara telah melakukan kerjasama pertukaran siswa untuk mengikuti beberapa program pendidikan. Sampai dengan tahun 2019, tercatat sebanyak 368 Prajurit TNI mengikuti pendidikan di India, dan sebaliknya 50 Prajurit India mengikuti pendidikan di Indonesia. Selain itu, bidang lain yang tidak kalah penting yang mendapatkan persetujuan dari kedua negara adalah kerja sama di bidang maritim, tidak hanya melihat peluang yang sangat besar untuk mendukung dan memperbesar peran kedua negara dalam mewujudkan stabilitas keamanan di kawasan khususnya Indo Pasifik, namun juga menunjang gagasan poros maritim dunia milik Indonesia (Kementerian Luar Negeri Republik Indonesia, 2019).

Dengan adanya respon tersebut, saat ini Pemerintah Indonesia masih merefleksikan relevansi kerjasama maritim dengan India sebagai potensi geopolitik yang berperan penting bagi posisi daya tawarnya di kawasan. 
Sebab tidak hanya melihat tindakan Indonesia yang mengeluarkan strategi geopolitik yang berorientasi pada penguatan jati diri sebagai negara maritim. Namun juga bagaimana di kawasan Indo Pasifik, Indonesia harus lebih proaktif mendorong perannya bersama India melalui kerjasama maritim sebagai kunci untuk bisa berkontribusi dalam tatanan politik di kawasan terkait.

Mengingat bahwa mereka memiliki visi yang sama dalam menciptakan kawasan Indo Pasifik yang terkendali, aman serta stabil untuk menjalankan segala aktivitas yang dibutuhkan tanpa adanya dominasi negara besar tertentu yang memungkinkan munculnya ketidakstabilan dan potensi konflik di kawasan. Dengan semakin menguatnya hubungan pertahanan dalam bidang maritim antara Indonesia-India juga memberikan mereka berdua posisi daya tawar yang kuat di kawasan secara bersama-sama mengingat bahwa latar belakang kekuatan geopolitik yang sama dalam Samudera Hindia, akan membentuk sebuah dinamika politik kawasan yang lebih stabil.

\section{Daftar Pustaka}

Auliya, Putri. dan Sulaiman, Yohanes. "Indonesia, ASEAN Centrality and Global Maritime Fulcrum” Jurnal Global \& Strategis Vol. 13 No. 1 Tahun 2019.

Baylis, John. et all. "The Globalization of World Politics : An Introduction to International Relations" Oxford University Press Inc., New York : 2008

Bhanu Singh, Udai. Emerging India-Indonesia Comprehensive Strategic Partnership. Journal of Defence Studies, Vol. 12, No. 3, July-September 2018, pp. 79-86

Bhatt, Pooja. "Evolving Dynamics in the Indo-Pacific Deliberating India's Position"

Chen, Dingding. Indo Pacific Strategy Background Analysis. https://www.ispionline.it/it/pubblicazione/indo-pacific-strategy-backg round-analysis-20714 diakses pada 6 Februari 2020 
G. Evans \& J. Newnham. "The Penguin Dictionary of International relations", Penguin Books, London, Uk : 1998

GK Today, "India-Indonesia Naval Exercise Samudera Shakti Begins" https://currentaffairs.gktoday.in/india-indonesia-naval-exercise-samu dra-shakti-begins-indonesia-11201862506.html diakses pada 30 Mei 2020

Gunawan, Dadang. et all. Diplomasi Pertahanan Indonesia Dalam Menyikapi Kompetisi India Dan China Di Samudera Hindia. Diplomasi Pertahanan Fakultas Strategi Pertahanan Universitas Pertahanan.

https://thediplomat.com/2017/02/the-future-of-india-indonesia-defense-ti es/diakses pada 30 Mei 2020

https://thediplomat.com/2019/05/5-big-ideas-for-the-indian-foreign-minis trys-new-indo-pacific-desk/ diakses pada 28 Mei 2020

https://www.airuniversity.af.edu/Portals/10/JIPA/journals/Volume-0 1 Issue-1/06 Bhatt.pdf diakses pada 28 Mei 2020

India Writes Network, "India, Indonesia transform ties, deepen Indo-Pacific connect" https://www.indiawrites.org/diplomacy/india-indonesia-transform-ties -deepen-indo-pacific-connect/ diakses pada 29 Mei 2020

Jash, Amrita. China, United States and the Changing Balance of Power in the Asia Pacific. http://earp.in/en/china-united-states-and-the-changing-balance-of-po wer-in-the-asia-pacific/ diakses pada 6 Februari 2020

Kantor Staf Presiden. Presiden Jokowi Presentasikan Konsep Indo-Pasifik di EAS.

http://ksp.go.id/presiden-jokowi-presentasikan-konsep-indo-pasifik-di -eas/index.html diakses pada 6 Februari 2020

Kementerian Luar Negeri Republik Indonesia, Indonesia Dan India Dorong Kerjasama Ekonomi Dan Maritim, diakses melalui https://kemlu.go.id/portal/id/read/579/berita/indonesia-india-doron g-kerja-sama-ekonomi-dan-maritim pada 29 Juni 2020 
Kementerian Luar Negeri Republik Indonesia, Indonesia Dorong Kerjasama Maritim ASEAN-India di Kawasan Indo Pasifik, diakses melalui https://kemlu.go.id/portal/id/read/188/berita/indonesia-dorong-kerj a-sama-maritim-asean-india-di-kawasan-Indo Pasifik pada 29 Juni 2020

Kementerian Luar Negeri Republik Indonesia, Indonesia Dorong Kerjasama Maritim ASEAN-India di Kawasan Indo Pasifik, diakses melalui https://kemlu.go.id/portal/id/read/188/berita/indonesia-dorong-kerj a-sama-maritim-asean-india-di-kawasan-Indo Pasifik pada 29 Juni 2020

Kementerian Luar Negeri Republik Indonesia, Pernyataan Pers Tahunan Menteri Luar Negeri Republik Indonesia Y.M. Retno L. P. Marsudi Tahun 9 Januari 2018. (Jakarta : Kementerian Luar Negeri Republik Indonesia, 2018)

Kementerian Luar Negeri Republik Indonesia."Rencana Strategis Kementerian Luar Negeri 2015-2019"(Jakarta : Kementerian Luar Negeri Republik Indonesia, 2015)

Kementerian Pertahanan Republik Indonesia, Menhan RI Terima Dubes India Bahas Peningkatan Kerjasama Pendidikan dan Latihan, diakses melalui

https://www.kemhan.go.id/2019/11/13/menhan-ri-terima-dubes-indi a-bahas-peningkatan-kerjasama-pendidikan-dan-latihan.html pada 29 Juni 2020

Kusumawardhani, Amanda. Indonesia Dorong Asean dan India Pererat Kerja Sama dalam Kerangka Indo Pasifik, diakses melalui https://kabar24.bisnis.com/read/20191103/19/1166363/indonesia-d orong-asean-dan-india-pererat-kerja-sama-dalam-kerangka-Indo

Pasifik pada 29 Juni 2020

Minghao, Zhao. Five Years On, BRI Tastes Success on Several Fronts. http://www.globaltimes.cn/content/1117400.shtm diakses pada 6 Februari 2020

Ministry of External Affairs Government of India. Shared Vision of India-Indonesia Maritime Cooperation in the Indo-Pacific. 
https://mea.gov.in/bilateral-18documents.htm?dtl/29933/Shared_Visi on_of_IndiaIndonesia_Maritime_Cooperation_in_the_IndoPacific diakses pada 6 Februari 2020

Parameswaran, Prashanth. "The Future of India-Indonesia Defense Ties"

PTI, "India, Indonesia decide to boost maritime cooperation" https://timesofindia.indiatimes.com/india/india-indonesia-decide-to-b oost-maritime-cooperation/articleshow/66337273.cms diakses pada 30 Mei 2020

Redaksi WE, Sambangi Indonesia Menlu India Dukung Visi Indo Pasifik, diakses melalui https://www.wartaekonomi.co.id/read245205/sambangi-indonesia-me nlu-india-dukung-visi-Indo Pasifik.html pada 29 Juni 2020

Setia Dewi, Suci. Implementasi Act East Policy India Dalam Kerjasama Keamanan Maritim India Dan Indonesia Periode 2015-2018. Ilmu Hubungan Internasional, Fakultas Ilmu Sosial Dan Ilmu Politik, Universitas Islam Negeri Syarif Hidayatullah Jakarta 2019

Singh, Hemant. "Meaning and Objectives of the Act East Policy of India" https://www.jagranjosh.com/general-knowledge/meaning-and-objectiv es-of-the-act-east-policy-of-india-1527251668-1 diakses pada 29 Mei 2020

Thakker, Aman. "5 Big Ideas for the Indian Foreign Ministry's New Indo-Pacific Desk",

Tisnadibrata, Ismira Lutfia. Indonesia India Sepakat Tingkatkan Kerjasama Maritim di Indo Pasifik, diakses melalui https://www.benarnews.org/indonesian/berita/indonesia-india-mariti m-05302018175326.html pada 29 Juni 2020

Tsvetov, Anton. Will the Quad Mean the End of ASEAN Centrality? https://thediplomat.com/2017/11/will-the-quad-mean-the-end-of-ase an-centrality diakses pada 6 Februari 2020

Vietnam News Agency. Vietnam among pillars of India's "Look East" policy. https://english.vietnamnet.vn/fms/government/89377/vietnam-amon g-pillars-of-india-s--look-east--policy.html diakses pada 6 Februari 2020 
Winger, Gregory. "The Velvet Gauntlet: A Theory of Defense Diplomacy. In: What Do Ideas Do?", ed. A. Lisiak, N. Smolenski, Vienna: IWM Junior Visiting Fellows' Conferences, Vol. 33 Tahun 2014. 